\title{
Extremely low genetic variability within and among locations of the greenfish holothurian Stichopus chloronotus Brandt, 1835 in Okinawa, Japan
}

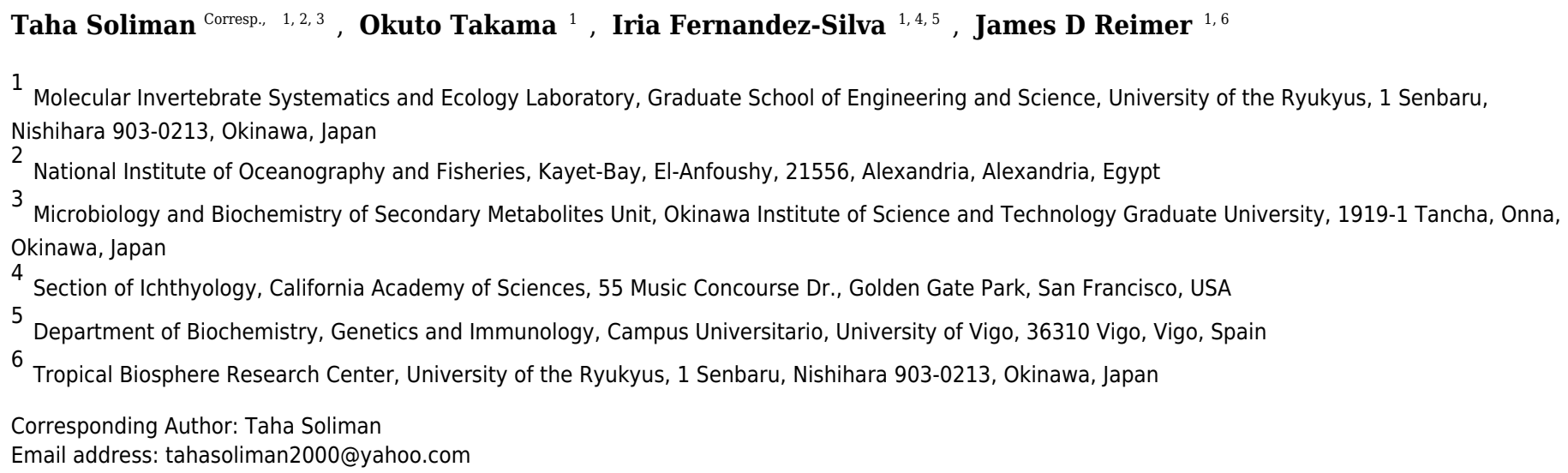

The greenfish sea cucumber Stichopus chloronotus is an economically and ecologically important sea cucumber species throughout its range. This species is widely distributed, inhabiting coral reefs of the Indo-Pacific Ocean. Our study evaluated population genetic structure and levels of genetic diversity in southern Japan. A total of 180 individuals were collected from eight locations from Okinawa and Okinoerabu Islands and sequenced using mitochondrial 16S ribosomal DNA (16S) and nuclear histone H3 (H3) gene. Only three 16S haplotypes were detected with 518 bp with haplotype diversity ranging from 0 to 0.56 and nucleotide diversity from 0 to $0.1 \%$. $\mathrm{H} 3$ showed no variation among the studied locations. It is plausible that such results could be due to a shift to asexual reproduction. Additionally, the presence of the species on the east coast of Okinawa could only be detected in one location and all individuals consisted of a single haplotype. Genetic differences between the east and west coasts of Okinawa have been noticed in other coral reef organisms, and attributed to either ecological or biogeographical historical differences between the coasts due to differing levels of isolation during Pleistocene ice ages. Results from the present study should inform management and conservation policies of $S$. chloronotus in southern Japan. 
1 Introduction

2

Sea cucumbers (holothurians) belong to class Holothuroidea of phylum Echinodermata and play an important and essential part in maintaining and structuring the marine ecosystem. They are deposit feeders of carbonate sand and rubble through their digestive tracts and dissolve

$\mathrm{CaCO}_{3}$ as part of their digestive process (Schneider et al. 2011). As 'ecosystem engineers', healthy populations of sea cucumbers are important for maintaining the continuing health of many marine ecosystems.

However, sea cucumbers of the order Aspidochirotida (families Holothuroidea and Stichopodidae) are suffering from overexploitation and overfishing in several countries (Anderson et al., 2011; Friedman et al., 2011; Purcell, 2010; Toral-Granda et al., 2008) due to high demand from Chinese and Southeast Asian markets, where they are consumed as food and utilized for traditional medicine (Bordbar et al., 2011). Unfortunately, statistics on fisheries/fishing activities for sea cucumbers are unavailable for many countries as most fisheries organizations still record invertebrate catch as 'others'. However, some organizations such as the Secretariat of the Pacific Community (SPC) and the Food and Agriculture Organization of the United Nations (FAO) have made efforts to make these records available for invertebrates including sea cucumbers.

The species Stichopus chloronotus Brandt, 1835 (greenfish sea cucumber), belonging to the family Stichopodidae, is a member of such highly commercial marine sea cucumber fisheries. This species is a widely distributed across most of the tropical Indo-Pacific region, from the Western Indian Ocean to the Central Pacific, and from southern Japan to northern Australia (Purcell et al., 2012). This species inhabits shallow waters from the intertidal zone to depths of $15 \mathrm{~m}$ and can be found on coral reef flats and slopes in dense numbers. Conand et al. (2002) reported on the sex ratios of S. chloronotus in some areas of the Indian and Pacific Oceans and 
25 found a very high number of males compared to females. S. chloronotus is known to reproduce

by two methods; sexual reproduction through indirect development (pelagic auricularia larvae) and asexually by transverse fission (Uthicke, 1997, 1999, 2001). In some marine invertebrates the pelagic larval stage, produced by sexual reproduction, has a large and long-term effect on gene flow via pelagic larval dispersal (Ellingson and Krug, 2016; Pechenik, 1999). The duration of the pelagic larval stage (PLD) of S. chloronotus is not well known, although it may be approximately 20 days as seen in other Stichopodidae (Soliman et al., 2013). In the northwestern Pacific, larval dispersal of $S$. chloronotus is influenced by the Kuroshio Current, which is a major ocean current bringing tropical water north from tropical regions along of the Ryukyu Archipelago and Japan's southeast Pacific coast (Barkley, 1970).

In Okinawa, Japan, similar to many other regions of the world, sea cucumbers have been under increasing commercial pressure due to high demand. A recent study showed that some populations of Holothuria edulis Lesson, 1830 around Okinawa Island had lower than expected genetic diversity, indicating potential overharvesting and/or ecosystem degradation (Soliman et al., 2016). Prefectural regulations have been put in place to try and limit further damage to sea cucumber populations, but basic genetic and abundance data are lacking for all other sea cucumber species for the entire Ryukyu Archipelago, and for Okinawa Island in particular. In order to properly conserve sea cucumbers around areas of large-scale human populations and coastal development like Okinawa Island, genetic population data are urgently needed.

Population genetic structure studies of S. chloronotus on the Great Barrier Reef have previously been carried out through polymorphic allozyme electrophoresis (Uthicke et al., 1999) and amplified fragment length polymorphism (AFLP) markers (Uthicke and Conand, 2005). In addition, there has been one study on the characterization of microsatellite markers for $S$. 
chloronotus utilizing specimens from the Ryukyu Islands, Japan, although there was no discussion of biogeographical findings (Taquet et al., 2011). The allozyme and AFLP studies suggested that population structure and genetic diversity of $S$. chloronotus is affected by asexual reproduction, with lower than expected genetic diversity due to the presence of clones.

In the present study we assess the genetic diversity and population structure among eight $S$. chloronotus locations in southern Japan (Okinawa and Okinoerabu Islands) using sequences of mitochondrial DNA (16S ribosomal DNA) and nuclear DNA (histone H3), in order to provide genetic connectivity. We examine whether $S$. chloronotus on the east and west coasts of Okinawa are genetically differentiated as has been observed in a number of recent studies on other sea cucumber (Soliman et al. 2016) and other invertebrate species (White et al., 2016). This information will be useful for future conservation and fisheries management. Based on recent increasing commercial pressure in Okinawa, we also expect that locations near to large human populations may show reduced $S$. chloronotus genetic diversity, as well as a potential shift to asexual reproduction due to reduced water quality, as was previously observed in $H$. edulis (Soliman et al. 2016).

\section{Materials and methods}

A total of 180 specimens of the greenfish sea cucumber S. chloronotus were collected from February to April 2015 by snorkeling and SCUBA diving at seven locations around Okinawa Island (Itoman, Oyama, Zanpa, Ryugu, Motobu, Yona, Teniya) and one location at Okinoerabu Island, Kagoshima, Japan (Table 1, Fig. 1). During our surveys, S. chloronotus was not found at any locations on the eastern coast of Okinawa Island asides from at Teniya (Soliman et al., unpublished data). Samples of $S$. chloronotus were obtained non-lethally through body wall-tissue biopsy $\left(1 \mathrm{~cm}^{2}\right)$ as in our previous study (Soliman et al. 2016) and preserved in 
absolute ethanol in the field. Live animals were released back to the same location from where they were collected.

Total genomic DNA was extracted from a small piece $(0.25 \mathrm{~g})$ of body wall tissue using a DNeasy Blood \& Tissue extraction kit (Qiagen, Tokyo, Japan) following the manufacturer's protocol. Polymerase chain reactions (PCR) were used to amplify fragments of two DNA markers; mitochondrial 16S and nuclear H3 gene, using the following primers: 16SA-R 5'- CGC CTG TTT ATC AAA AAC AT -3'; 16SB-R 5'- GCC GGT CTG AAC TCA GAT CAC GT -3' (Palumbi et al., 1991), and H3a: 5'- ATG GCT CGT ACC AAG CAG ACV GC -3'; H3b: 5'ATA TCC TTR GGC ATR ATR GTG AC -3' (Colgan et al., 1998), respectively. Amplification reactions were carried out in a $15 \mu \mathrm{l}$ volume containing 5 to $20 \mathrm{ng}$ of template genomic DNA, $0.5 \mu \mathrm{M}$ of each primer, and $10 \mu 1$ of HotStarTaqTM Master Mix (Qiagen, Tokyo, Japan), in deionized water. PCR reactions were performed on an Eppendorf thermocycler (Eppendorf AG, Hamburg, Germany) with an initial denaturation step at $95^{\circ} \mathrm{C}$ for 15 min, 35 cycles of denaturation at $94^{\circ} \mathrm{C}$ for $1 \mathrm{~min}$, an annealing at $46^{\circ} \mathrm{C}(16 \mathrm{~S})$ and $48^{\circ} \mathrm{C}(\mathrm{H} 3)$ for 1 min, extension at $72^{\circ} \mathrm{C}$ for $1 \mathrm{~min}$, and a final extension step at $72^{\circ} \mathrm{C}$ for $10 \mathrm{~min}$. The amplification products were tested using electrophoresis (1.5\% agarose gel) and purified with Exonuclease I and Alkaline Phosphatase Shrimp (Takara) and incubated at $37^{\circ} \mathrm{C}$ for $20 \mathrm{~min}$, followed by deactivation at $83^{\circ} \mathrm{C}$ for $30 \mathrm{~min}$. Purified PCR products were sequenced using an ABI Prism automated sequencer at Fasmac Co., Kanagawa, Japan (http://www.fasmac.co.jp/index.html), in both in forward and reverse directions.

Consensus sequences of $16 \mathrm{~S}$ and $\mathrm{H} 3$ were aligned and edited using Geneious v.8.1.3 (http://www.geneious.com, (Kearse et al., 2012), and MEGA v.6.0 (Tamura et al., 2013). The H3 sequences showed no variation and no additional analyses were conducted. For 16S, number of haplotypes $(\boldsymbol{h})$, haplotype diversity $\left(\boldsymbol{h}_{\boldsymbol{d}}\right)$ and nucleotide diversity $(\boldsymbol{\pi})$ were estimated with DNASP 
97 v.5.10.01 (Librado and Rozas, 2009). The best-fit model of DNA sequence evolution was 98 estimated using MEGA v.6.0 (Tamura et al., 2013). The AIC (Akaike Information Criterion)

99 indicated that Jukes-Cantor (JC) was the best-fit model. We computed pairwise $\Phi_{S T}$ and average 100 of pairwise differences (Nei's distance, within and between locations) for all pairs of locations 101 using Arlequin 3.5.1.2 (Excoffier and Lischer, 2010; Weir and Cockerham, 1984). The 102 simultaneous tests correction was adjusted using the modified false discovery rate (FDR) method 103 (Narum 2006). To investigate genetic partitioning among regions, among locations within 104 regions, and between all locations we applied a hierarchical analysis of molecular variance 105 (AMOVA), using Arlequin, and tested the following hypothesis; A - Three groups: Okinoerabu 106 Island as group 1, Teniya (east) as group 2 and all other western locations (Itoman, Motobu, 107 Oyama, Ryugu, Yona, Zanpa) as group 3; and B - Two groups: Teniya from east as group 1 and

western locations of Okinawa Island (Itoman, Motobu, Oyama, Ryugu, Yona, Zanpa) plus Okinoerabu Island as group 2. Principal Coordinates Analysis (PCoA) based on 16S haplotype frequencies among locations were calculated and visualized using PAST 3.11 (Hammer et al., 2001).

\section{Results}

We obtained sequences of a 518 bp fragment of $16 \mathrm{~S}$ from 175 specimens (GenBank Accession numbers KX522950-KX523124) from eight total locations around Okinawa and Okinoerabu Islands (Table 1, Figure 1). The alignment of 16S sequences resulted in three haplotypes: Hap_1 was common among seven locations (Itoman, Oyama, Zanpa, Ryugu, Motobu, Yona, Okinoerabu), Hap_2 was shared among five locations (Itoman, Oyama, Ryugu, Motobu, Teniya), and Hap_3 was exclusive to Oyama (Figure 1 and 2). Four locations showed no haplotype diversity for 16S; all 69 sea cucumbers sampled in Zanpa, Yona (both on 
121 Okinawa's west coast), and Okinoerabu were Hap_1 while all 15 specimens sampled at Teniya 122 (Okinawa's east coast) consisted of Hap_2 (Table 1 and Fig. 1). Overall, the haplotype diversity 123 was low $\left(\boldsymbol{h}_{\boldsymbol{d}}=0.36\right)$, and was highest in the Oyama $\left(\boldsymbol{h}_{\boldsymbol{d}}=0.558\right)$ and Ryugu $\left(\boldsymbol{h}_{\boldsymbol{d}}=0.5143\right)$ 124 locations. In addition, the nucleotide diversity of $16 \mathrm{~S}$ was low for all locations combined $(\boldsymbol{\pi}=$ $125 \quad$ 0.0008; Table 1).

126

127 128

129

130

131

132

133

134

135

136 137

We also obtained a $307 \mathrm{bp}$ fragment of the nuclear H3 gene from 180 individuals of $S$. chloronotus collected in the same locations around Okinawa and Okinoerabu Islands. Obtained H3 sequences showed no variation. Therefore, all subsequent population genetics analyses were based on $16 \mathrm{~S}$ data only.

Significant pairwise $\Phi_{S T}$ values were found in 17 out of 28 comparisons after multiple tests correction $(P<0.01)$ (Table 2). Most of the significant comparisons were between locations not sharing haplotypes, Teniya (east coast of Okinawa Island) vs Yona and Zanpa (west coast of Okinawa Island) or with Okinoerabu Island. Although the null hypothesis of panmixia in the overall AMOVA test (global $\Phi_{S T}=0.559, P<0.001$ ) was rejected, results of the hierarchical AMOVAs did not support significant differences between east and west coasts or between north (Okinoerabu Island), east of Okinawa Island (Teniya) and west of Okinawa Island (Itoman, Motobu, Oyama, Ryugu, Yona, Zanpa) (Table 3).

Principle Coordinates Analyses (PCoA) using overall pairwise $\Phi_{S T}$ for $16 \mathrm{~S}$ revealed three clusters; 1) Yona, Zanpa, Motobu, Itoman and Okinoerabu, 2) Ryugu and Oyama, and 3) Teniya (Figure 4).

\section{Discussion}

The present study revealed low levels of genetic diversity of the greenfish sea cucumber within and between the southern Ryukyu Islands of Japan, with only three haplotypes in $16 \mathrm{~S}$ and one in 
145 H3. These low levels of polymorphism in $S$. chloronatus impose some caution in the overall 146 interpretation of results. Various studies of $S$. chloronotus across regions using different genetic

147 148 markers have also revealed low genetic diversity. Uthicke and Conand (2005) observed low genetic diversity in the southwestern Pacific (Great Barrier Reef, Torres Strait) compared to the western Indian Ocean using amplified fragment length polymorphism (AFLP) analyses, and suggested that AFLP markers are a suitable method to examine clonality in sea cucumbers. In addition, allozyme studies have showed a low number of polymorphic loci in $S$. chloronotus in some locations such as the Great Barrier Reef, Torres Strait, and La Reunion (Uthicke et al., 1999; Uthicke et al., 2001). The low genetic diversity results may stem from reported high rates of asexual reproduction in $S$. chloronotus in several other Indo-Pacific regions, as well as a biased male sex ratio (Conand et al., 2002). In addition, strong variation of rates of asexual reproduction over small geographic scales in $S$. chloronotus has been reported in genetic surveys and reproductive biology studies (Conand et al., 2002; Uthicke et al., 1999). This pattern seems to be common in other sea cucumbers: low genetic diversity has been observed in Holothuria edulis around Okinawa Island using mitochondrial (16S and COI) and nuclear $\mathrm{H} 3$ genes (Soliman et al., 2016), and in Holothuria atra in Okinawa and the Ogasawara Islands based on COI sequences (Skillings et al., 2011). We posit that our observations of low genetic diversity could be attributed to shifts to asexual reproduction in $S$. chloronotus. (eutrophication) and small individual sizes (caused by over-exploitation) have been identified as the most important factors that can lead to asexual reproduction in sea cucumbers (Conand et al., 2002). Over the past 40 years, coastal development and landfill have reduced and degraded shallow water habitats and water quality along the shoreline of Okinawa Island, and this has been 
168 implicated in reductions in biodiversity of near-shore marine communities (Reimer et al., 2015).

169 These anthropogenic impacts may also at least partially explain the reduction in genetic diversity

170 among these locations. Overharvesting can also lead to reductions of genetic diversity (Smith et

171 al. 1991; Pinsky et al. 2014) and from our field observations at different sites of Okinawa Island 172 it appears that some sea cucumber species such as H. edulis and S. chloronotus are overexploited 173 (Soliman et al., 2016). Similar anecdotal evidence on a reduction in sea cucumber numbers led 174 Okinawa Prefecture to implement a harvesting licensing system in 2013 with further 175 strengthening in 2016.

176 The haplotype frequency differences between the west coast of Okinawa and the single location 177 on the east coast may be due to the existence of habitat differences, oceanographic barriers to 178 dispersal promoting a reduction of larval exchange, and/or historical factors. We extensively

searched for $S$. chloronatus individuals on the east coast, however, Teniya was the only location on this coast where the species could be found, further indicating the possibility of the above mentioned factors. Furthermore, our results indicated the presence of gene exchange among all Okinawa Island west coast locations and Okinoerabu Island. This pattern is consistent with the route of the Kuroshio Current flowing northward to the west of Okinawa Island (Figure 1), and suggests this current may play a key role in connecting locations of $S$. chloronatus. On the other hand, areas isolated from the Kuroshio Current, such as the east coast of Okinawa Island, may harbor genetically distinct populations. Extensive geographic fine grid surveys on the east coast of Okinawa Island and from regions more isolated from the Kuroshio Current (e.g. the Daito Islands $310 \mathrm{~km}$ to the east of Okinawa Island; the disputed Senkaku Islands $410 \mathrm{~km}$ west of Okinawa Island) in southern Japan are needed to confirm this assertion. Similar patterns of genetic differentiation between east and west Okinawa Island locations have been observed in recent studies on the sea cucumber Holothuria edulis (Soliman et al., 2016) and in the amphipod 
192 Leucothoe vulgaris (White et al., 2016),. White et al. (2016) suggested this reduction caused by

193 Pleistocene sea level changes (Ni et al., 2014) and/or geographic discontinuity (Castelin et al.,

194 2012). In contrast, in one species of scleractinian coral (Acropora digitifera), Okinawa Island

195 locations from both east and west coasts showed no separation and were treated as one panmictic 196 population (Shinzato et al., 2015). Differences in the level of genetic structure could be 197 explained by the shorter pelagic larval duration in the sea cucumber [approx. 20 days in 198 Stichopodidae; Soliman et al. (2013)] than in A. digitifera [approx. 45 days; Nishikawa and

Sakai (2005)]. However, multiple studies point to the complexity of making predictions on genetic connectivity based on the length of pelagic larval development (e.g. Selkoe et al., 2014; Shanks, 2009). Nevertheless, from the few population genetics studies published in sea cucumbers to date (Eastwood et al. 2016; Skillings et al., 2014; Soliman et al., 2016; Valente et al., 2015; Vergara-Chen et al., 2010) there is a generalized pattern of highly geographically structured genetic variation and reduced dispersal ability, which may compromise the persistence of sea cucumber populations and species when facing intense fishing pressure, habitat degradation, or other environmental threats.

In conclusion, the present genetic survey of $S$. chloronotus indicates low levels of genetic diversity and reduced genetic exchange among sites in Okinawa and Okinoerabu islands, and particularly between the east and west coasts of Okinawa Island. These results will be useful for fisheries management decisions regarding this species in southern Japan. Both Soliman et al. (2016) and the present study also suggest that more research on sea cucumbers is needed from the Ryukyu Islands in order to properly conserve and protect the genetic diversity of these economic and ecologically important animals. 


\section{Acknowledgments}

216 S. Hisashi is deeply thanked for his help on Okinoerabu Island - he will be deeply missed. We

217 also thank R. Diaz for help with sample collection and members of the MISE laboratory for their

218 logistic and scientific support.

219

220

\section{References}

221

222

223

224

225

226

227

228

229

230

231

232

233

234

235

236

237

238

239

240

241

242

Anderson SC, Flemming JM, Watson R, and Lotze HK. 2011. Serial exploitation of global sea cucumber fisheries. Fish and Fisheries 12:317-339. 10.1111/j.1467-2979.2010.00397.x

Barkley RA. 1970. The Kuroshio Current. Science Journal 6:54-60.

Bordbar S, Anwar F, and Saari N. 2011. High-value components and bioactives from sea cucumbers for functional foods-a review. Marine Drugs 9:1761-1805. 10.3390/md9101761

Borrero-Perez GH, Gonzalez-Wanguemert M, Marcos C, and Perez-Ruzafa A. 2011. Phylogeography of the Atlanto-Mediterranean sea cucumber Holothuria (Holothuria) mammata: the combined effects of historical processes and current oceanographical pattern. Molecular Ecology 20:19641975. 10.1111/j.1365-294X.2011.05068.x

Castelin M, Lorion J, Brisset J, Cruaud C, Maestrati P, Utge J, and Samadi S. 2012. Speciation patterns in gastropods with long-lived larvae from deep-sea seamounts. Molecular Ecology 21:4828-4853. 10.1111/j.1365-294X.2012.05743.x

Colgan DJ, McLauchlan A, Wilson GDF, Livingston S, Macaranas J, Edgecombe GD, Cassis G, and Gray MR. 1998. Molecular phylogenetics of the Arthropoda: relationships based on histone H3 and U2 snRNA DNA sequences. Australian Journal of Zoology 46:419-437.

Conand C, Uthicke S, and Hoareau T. 2002. Sexual and asexual reproduction of the holothurian Stichopus chloronotus (Echinodermata): a comparison between La Reunion (Indian Ocean) and east Australia (Pacific Ocean). Invertebrate Reproduction \& Development 41:235-242. $10.1080 / 07924259.2002 .9652756$

Eastwood EK, Lopez EH, and Drew JA. 2016. Population connectivity measures of fishery-targeted coral reef species to inform marine reserve network design in Fiji. Scientific Reports 6:19318. $10.1038 /$ srep 19318 
243

244

245

246

247

248

249

250

251

252

Ellingson RA, and Krug PJ. 2016. Reduced genetic diversity and increased reproductive isolation follow population-level loss of larval dispersal in a marine gastropod. Evolution 70:18-37. 10.1111/evo. 12830

Excoffier L, and Lischer HEL. 2010. Arlequin suite ver 3.5: a new series of programs to perform population genetics analyses under Linux and Windows. Molecular Ecology Resources 10:564567. 10.1111/j.1755-0998.2010.02847.x

Friedman K, Eriksson H, Tardy E, and Pakoa K. 2011. Management of sea cucumber stocks: patterns of vulnerability and recovery of sea cucumber stocks impacted by fishing. Fish and Fisheries 12:7593. 10.1111/j.1467-2979.2010.00384.x

Fu YX. 1997. Statistical tests of neutrality of mutations against population growth, hitchhiking and background selection. Genetics 147:915-925.

Hammer Ø, Harper DAT, and Ryan PD. 2001. PAST: Paleontological Statistics software package for education and data analysis. Palaeontologia Electronica 4:1-9.

Kearse M, Moir R, Wilson A, Stones-Havas S, Cheung M, Sturrock S, Buxton S, Cooper A, Markowitz S, Duran C, Thierer T, Ashton B, Meintjes P, and Drummond A. 2012. Geneious Basic: an integrated and extendable desktop software platform for the organization and analysis of sequence data. Bioinformatics 28:1647-1649. 10.1093/bioinformatics/bts199

Librado P, and Rozas J. 2009. DnaSP v5: a software for comprehensive analysis of DNA polymorphism data. Bioinformatics 25:1451-1452. 10.1093/bioinformatics/btp187

Ni G, Li Q, Kong L, and Yu H. 2014. Comparative phylogeography in marginal seas of the northwestern Pacific. Molecular Ecology 23:534-548.

Nishikawa A, and Sakai K. 2005. Settlement-competency period of planulae and genetic differentiation of the scleractinian coral Acropora digitifera. Zoological Science 22:391-399. 10.2108/zsj.22.391

Palumbi SR, Martin AP, Romano S, Mcmilla WO, Stice L, and Grabowski G. 1991. The simple fool's guide to PCR. Department of Zoology, University of Hawai 'i, Honolulu.

Pechenik JA. 1999. On the advantages and disadvantages of larval stages in benthic marine invertebrate life cycles. Marine Ecology Progress Series 177:269-297. 10.3354/meps177269

Pinsky ML, and Palumbi SR. 2014. Meta-analysis reveals lower genetic diversity in overfished 
populations. Molecular Ecology 23.1: 29-39.

Purcell SW. 2010. Managing sea cucumber fisheries with an ecosystem approach, Edited/compiled by Lovatelli, A.; M. Vasconcellos and Y. Yimin. FAO Fisheries and Aquaculture Technical Paper; 520 Rome: 157.

Purcell SW, Samyn Y, Conand C, and Food and Agriculture Organization of the United Nations. 2012. Commercially important sea cucumbers of the world. Rome: Food and Agriculture Organization of the United Nations.

Reimer JD, Yang SY, White KN, Asami R, Fujita K, Hongo C, Ito S, Kawamura I, Maeda I, Mizuyama M, Obuchi M, Sakamaki T, Tachihara K, Tamura M, Tanahara A, Yamaguchi A, and JenkeKodama H. 2015. Effects of causeway construction on environment and biota of subtropical tidal flats in Okinawa, Japan. Marine Pollution Bulletin 94:153-167. 10.1016/j.marpolbul.2015.02.037

Selkoe KA, Gaggiotti OE, Bowen BW, Toonen RJ, and ToBo L. 2014. Emergent patterns of population genetic structure for a coral reef community. Molecular Ecology 23:3064-3079. $10.1111 / \mathrm{mec} .12804$

Schneider K, Silverman J, Woolsey E, Eriksson H, Byrne M, Caldeira K. 2011. Potential influence of sea cucumbers on coral reef $\mathrm{CaCO} 3$ budget: a case study at One Tree Reef. Journal of Geophysical Research 116:G04032.

Shanks AL. 2009. Pelagic larval duration and dispersal distance revisited. Biological Bulleetin 216:373385.

Shinzato C, Mungpakdee S, Arakaki N, and Satoh N. 2015. Genome-wide SNP analysis explains coral diversity and recovery in the Ryukyu Archipelago. Scientific Reports 5:18211. $10.1038 /$ srep 18211

Skillings DJ, Bird CE, and Toonen RJ. 2011. Gateways to Hawai'i: genetic population structure of the tropical sea cucumber Holothuria atra. Journal of Marine Biology:10.1155/2011/783030.

Skillings DJ, Bird CE, and Toonen RJ. 2014. Comparative population structure of two edible Indo-Pacific coral reef sea cucumbers (Echinodermata: Holothuroidea). Bulletin of Marine Science 90:359-378. $10.5343 /$ bms.2013.1001

Soliman T, Fernandez-Silva I, and Reimer JD. 2016. Genetic population structure and low genetic diversity in the over-exploited sea cucumber Holothuria edulis Lesson, 1830 (Echinodermata: 
300

301

302

303

304

305

306

307

308

309

310

311

312

313

314

Holothuroidea) in Okinawa Island. Conservation Genetics:1-11. 10.1007/s10592-016-0823-8

Soliman T, Yamazaki Y, Niiyama H, and Tsunoda K. 2013. Spontaneous captive breeding and larval development in the green and red variants of the Japanese sea cucumber Apostichopus japonicus (Selenka 1867). Aquaculture Research 44:738-746. 10.1111/j.1365-2109.2011.03078.x

Smith PJ, Francis RICC, and McVeagh M. 1991. Loss of genetic diversity due to fishing pressure. Fisheries Research 10.3-4: 309-316.

Stephens M, and Donnelly P. 2003. A comparison of Bayesian methods for haplotype reconstruction from population genotype data. American Journal of Human Genetics 73:1162-1169. 10.1086/379378

Tamura K, Stecher G, Peterson D, Filipski A, and Kumar S. 2013. MEGA6: Molecular Evolutionary Genetics Analysis Version 6.0. Molecular Biology and Evolution 30:2725-2729. 10.1093/molbev/mst197

Taquet C, Nagai S, Yasuda N, and Nadaoka K. 2011. First report of the development of microsatellite markers for a tropical sea cucumber (Stichopus chloronotus). Conservation Genetics Resources 3:201-203. 10.1007/s12686-010-9322-2

Toral-Granda V, Lovatelli A, and Vasconcellos M. 2008. Sea cucumbers: a global review of fisheries and trade. FAO Fisheries and Aquaculture Technical Paper, 516 FAO, Rome.

Uthicke S. 1997. Seasonality of asexual reproduction in Holothuria (Halodeima) atra, H. (H.) edulis and Stichopus chloronotus (Holothuroidea: Aspidochirotida) on the Great Barrier Reef. Marine Biology 129:435-441. 10.1007/s002270050184

Uthicke S. 1999. Sediment bioturbation and impact of feeding activity of Holothuria (Halodeima) atra and Stichopus chloronotus, two sediment feeding holothurians, at Lizard Island, Great Barrier Reef. Bulletin of Marine Science 64:129-141.

Uthicke S. 2001. Influence of asexual reproduction on the structure and dynamics of Holothuria (Halodeima) atra and Stichopus chloronotus populations of the Great Barrier Reef. Marine and Freshwater Research 52:205-215. 10.1071/Mf00064

Uthicke S, Benzie JAH, and Ballment E. 1999. Population genetics of the fissiparous holothurian Stichopus chloronotus (Aspidochirotida) on the Great Barrier Reef, Australia. Coral Reefs 18:123-132. 10.1007/s003380050166 
Uthicke S, and Conand C. 2005. Amplified fragment length polymorphism (AFLP) analysis indicates the importance of both asexual and sexual reproduction in the fissiparous holothurian Stichopus chloronotus (Aspidochirotida) in the Indian and Pacific Ocean. Coral Reefs 24:103-111. 10.1007/s00338-004-0441-7

Uthicke S, Conand C, and Benzie JAH. 2001. Population genetics of the fissiparous holothurians Stichopus chloronotus and Holothuria atra (Aspidochirotida): a comparison between the Torres Strait and La Reunion. Marine Biology 139:257-265.

Valente S, Serrao EA, and Gonzalez-Wanguemert M. 2015. West versus East Mediterranean Sea: origin and genetic differentiation of the sea cucumber Holothuria polii. Marine Ecology-an Evolutionary Perspective 36:485-495. 10.1111/maec.12156

Vergara-Chen C, Gonzalez-Wanguemert M, Marcos C, and Perez-Ruzafa A. 2010. Genetic diversity and connectivity remain high in Holothuria polii (Delle Chiaje 1823) across a coastal lagoon-open sea environmental gradient. Genetica 138:895-906. 10.1007/s10709-010-9472-x

Weir BS, and Cockerham CC. 1984. Estimating F-statistics for the analysis of population-structure. Evolution 38:1358-1370. 10.2307/2408641

White KN, Reimer JD, and Lorion J. 2016. Preliminary analyses reveal strong genetic structure in populations of Leucothoe vulgaris (Crustacea: Amphipoda: Leucothoidae) from Okinawa, Japan. Systematics and Biodiversity 14:55-62. 10.1080/14772000.2015.1078856

\section{Table legends}

Table 1 Molecular diversity of Stichopus chloronotus of mitochondrial 16S ribosomal DNA sequences from eight locations in southern Japan ( $n$ : Sample size; $h$ : number of haplotypes; $h_{\mathrm{d}}$ : haplotype diversity; $\pi$ : nucleotide diversity).

Table 2 Pairwise estimates of $\Phi_{\mathrm{ST}}$ among eight locations of Stichopus chloronotus in southern Japan inferred from a 518 bp DNA fragment of the mitochondrial 16S ribosomal gene from 175 specimens.

Table 3 Hierarchical analyses of molecular variance (AMOVA) based a $518 \mathrm{bp}$ fragment of the mitochondrial 16S ribosomal gene from 175 specimens of $S$. chloronotus testing different hypotheses of geographical groupings among eight locations in southern Japan. Hypothesis A: 
359 Group 1 = Okinoerabu Island, Group 2 = Teniya, Group 3 = Itoman, Motobu, Oyama, Ryugu, 360 Yona, Zanpa. Hypothesis B: Group 1 = Okinoerabu, Itoman, Motobu, Oyama, Ryugu, Yona, 361 Zanpa, Group 2 = Teniya.

362

363 Figure legends

364 Figure 1. Map with sampling locations and frequency of 16S ribosomal DNA haplotypes of 365 Stichopus chloronotus from Okinawa and Okinoerabu Islands, Japan. The arrows depict the 366 prevailing path and direction of the Kuroshio Current.

Figure 2. Median-joining haplotype network inferred from 16S ribosomal DNA sequences of Stichopus chloronotus. Each circle represents a different haplotype and the size of a circle is proportional to the frequency of each haplotype. Colours denote the proportion of haplotypes collected at each location as indicated by the embedded key. Haplotypes separated by black crossbars differ by a single nucleotide, whereas hatch marks indicate unsampled haplotypes.

Figure 3. Average number of pairwise differences within and among locations of Stichopus chloronotus for $16 \mathrm{~S}$ ribosomal DNA.

Figure 4. Principal Coordinates Analysis (PCoA) based on 16S ribosomal DNA haplotype 378 frequencies of Stichopus chloronotus locations from Okinawa and Okinoerabu Islands. 


\section{Table $\mathbf{1}$ (on next page)}

Molecular diversity of Stichopus chloronotus of mitochondrial 16S ribosomal DNA (16S) sequences from eight locations (= populations) in southern Japan ( $n$ : Sample size; $h$ : number of haplotypes; hd: hap 
1

\begin{tabular}{lcccccccc}
\hline \multicolumn{1}{c}{ Locations } & Lat. and Long. & $\boldsymbol{n}$ & $\boldsymbol{h}$ & $\boldsymbol{h}_{\boldsymbol{d}}$ & $\boldsymbol{\pi}$ & Fu's Fs & $\begin{array}{c}\text { Fu's Fs p- } \\
\text { value }\end{array}$ \\
\hline & & & & & & & & \\
Okinoerabu Island & $27^{\circ} 25^{\prime} 05.2^{\prime \prime} \mathrm{N} 128^{\circ} 39^{\prime} 00.6^{\prime \prime} \mathrm{E}$ & 24 & 1 & 0.0000 & 0.0000 & 0.0000 & N.A. \\
Yona, Okinawa Island & $26^{\circ} 45^{\prime} 56.6^{\prime \prime} \mathrm{N} 128^{\circ} 11^{\prime} 42.4^{\prime \prime} \mathrm{E}$ & 24 & 1 & 0.0000 & 0.0000 & 0.0000 & N.A. \\
Motobu, Okinawa Island & $26^{\circ} 40^{\prime} 45.8^{\prime \prime} \mathrm{N} 127^{\circ} 52^{\prime} 55.4^{\prime \prime} \mathrm{E}$ & 24 & 2 & 0.0833 & 0.0002 & -1.0279 & 0.079 \\
Ryugu, Okinawa Island & $26^{\circ} 31^{\prime} 48.6^{\prime \prime} \mathrm{N} 127^{\circ} 55^{\prime} 34.8^{\prime \prime} \mathrm{E}$ & 21 & 2 & 0.5143 & 0.0011 & 1.4737 & 0.757 \\
Zanpa, Okinawa Island & $26^{\circ} 25^{\prime} 58.8^{\prime \prime} \mathrm{N} 127^{\circ} 42^{\prime} 57.2^{\prime \prime} \mathrm{E}$ & 21 & 1 & 0.0000 & 0.0000 & 0.0000 & N.A. \\
Oyama, Okinawa Island & $26^{\circ} 17^{\prime} 01.2^{\prime \prime} \mathrm{N} 127^{\circ} 44^{\prime} 20.5^{\prime \prime} \mathrm{E}$ & 22 & 3 & 0.5584 & 0.0013 & 0.1995 & 0.504 \\
Itoman, Okinawa Island & $26^{\circ} 07^{\prime} 15.1^{\prime \prime} \mathrm{N} 127^{\circ} 39^{\prime} 34.7^{\prime \prime} \mathrm{E}$ & 24 & 2 & 0.1594 & 0.0003 & -0.2489 & 0.212 \\
Teniya, Okinawa Island & $26^{\circ} 33^{\prime} 52.6^{\prime \prime} \mathrm{N} 128^{\circ} 08^{\prime} 16.0^{\prime \prime} \mathrm{E}$ & 15 & 1 & 0.0000 & 0.0000 & 0.0000 & N.A. \\
\hline
\end{tabular}

2 


\section{Table 2 (on next page)}

Pairwise estimates of $\Phi S T$ among eight populations of Stichopus chloronotus in southern Japan inferred from a 518 bp DNA fragment of the mitochondrial $16 \mathrm{~S}$ ribosomal gene from 175 specimens. 
1

\begin{tabular}{lrrrrrrrr}
\hline \multicolumn{1}{c}{ Location } & Okinoerabu & Yona & Motobu & Ryugu & Zanpa & Oyama & Itoman & Teniya \\
\hline Okinoerabu & 0.000 & & & & & & & \\
Yona & 0.000 & 0.000 & & & & & & \\
Motobu & 0.020 & 0.000 & 0.000 & & & & & \\
Ryugu & $\mathbf{0 . 5 6 9}$ & $\mathbf{0 . 5 6 9}$ & $\mathbf{0 . 4 8 6}$ & 0.000 & & & & \\
Zanpa & 0.000 & 0.000 & 0.006 & $\mathbf{0 . 5 5 0}$ & 0.000 & & & \\
Oyama & $\mathbf{0 . 4 4 1}$ & $\mathbf{0 . 4 4 1}$ & $\mathbf{0 . 3 5 1}$ & 0.021 & $\mathbf{0 . 4 2 2}$ & 0.000 & & \\
Itoman & 0.044 & 0.044 & 0.028 & $\mathbf{0 . 4 0 8}$ & 0.036 & $\mathbf{0 . 2 7 1}$ & 0.000 & \\
Teniya & $\mathbf{1 . 0 0 0}$ & $\mathbf{1 . 0 0 0}$ & $\mathbf{0 . 9 4 7}$ & $\mathbf{0 . 3 5 5}$ & $\mathbf{1 . 0 0 0}$ & $\mathbf{0 . 4 7 3}$ & $\mathbf{0 . 8 9 4}$ & 0.000 \\
\hline
\end{tabular}

2 Significant $\Phi_{S T}$ at $P<0.01$ following the False Discovery Rate (FDR) correction

3 (Narum, 2006) indicated in bold.

4

5 


\section{Table 3(on next page)}

Hierarchical analyses of molecular variance (AMOVA) based a 518 bp fragment of the mitochondrial $16 \mathrm{~S}$ ribosomal gene from 175 specimens of S. chloronotus testing different hypotheses of geographical gr 
1

\begin{tabular}{|c|c|c|c|c|c|c|c|c|c|c|}
\hline Variation & d.f. & SS & $\begin{array}{c}\text { Variation } \\
(\%)\end{array}$ & Fixation indices & $P$ value & d.f. & SS & $\begin{array}{c}\text { Variation } \\
(\%)\end{array}$ & $\begin{array}{l}\text { Fixation } \\
\text { indices }\end{array}$ & $P$ value \\
\hline Hypothesis & & & & & & & & & & \\
\hline Among groups & 2 & 17.22 & 47.08 & $\Phi_{C T}=0.4781$ & 0.1691 & 1 & 16.09 & 70.85 & $\Phi_{C T}=0.7085$ & 0.1202 \\
\hline $\begin{array}{l}\text { Among population } \\
\text { within groups }\end{array}$ & 5 & 11.56 & 20.28 & $\Phi_{S C}=0.3885$ & $<0.0001$ & 6 & 12.7 & 11.56 & $\Phi_{S C}=0.3966$ & $<0.0001$ \\
\hline Within populations & 167 & 22.06 & 31.91 & $\Phi_{S T}=0.6782$ & $<0.0001$ & 167 & 22.06 & 17.59 & $\Phi_{S T}=0.8241$ & $<0.0001$ \\
\hline
\end{tabular}

2 d.f.: degree of freedom; SS: sum of squares

3 
Figure 1

Map with sampling locations and frequency of 16S ribosomal DNA (16S) haplotypes of Stichopus chloronotus from Okinawa and Okinoerabu Islands, Japan. The arrows depict the prevailing path and direction

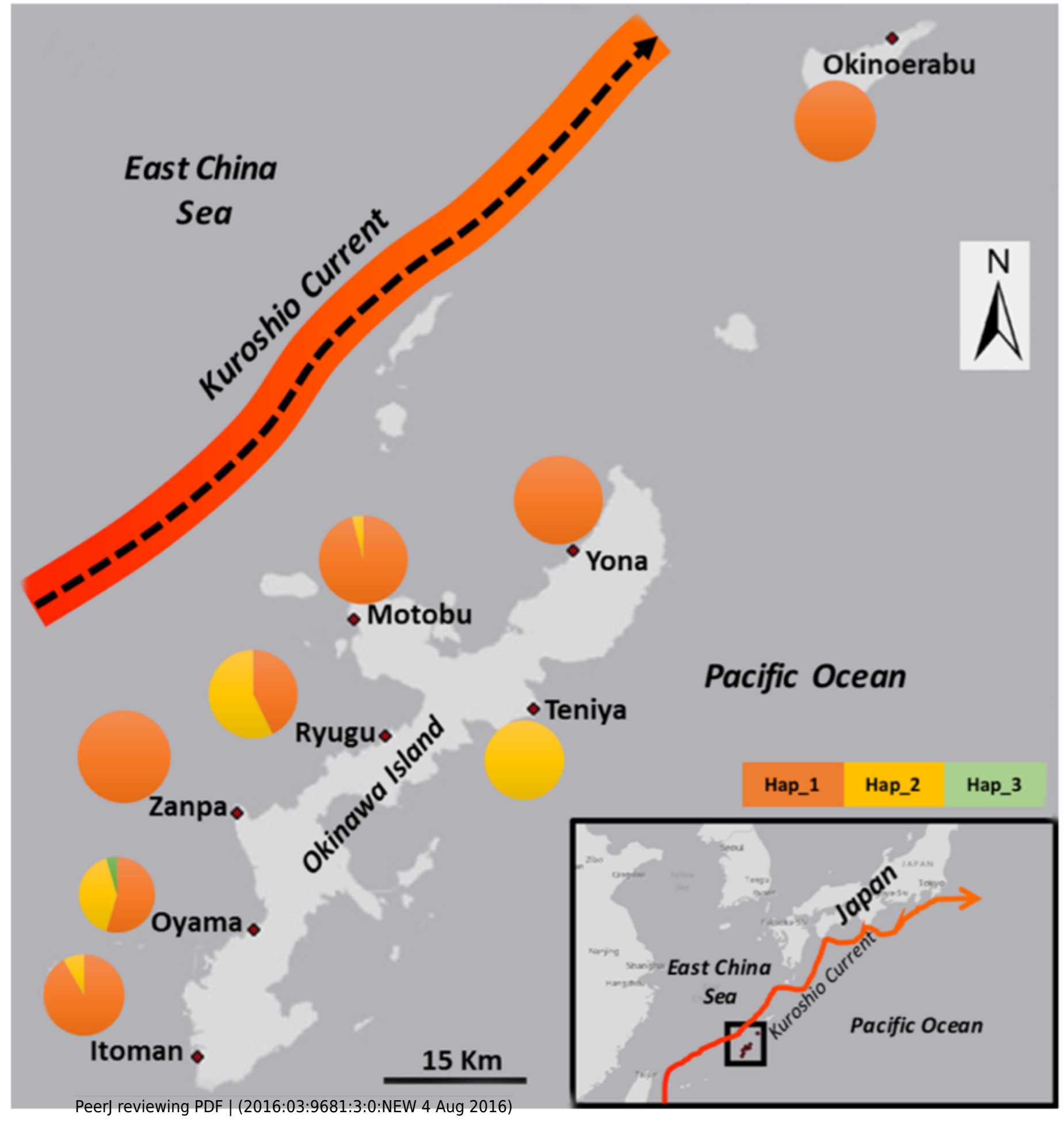




\section{Figure 2}

Median-joining haplotype network inferred from 16S ribosomal DNA sequences of Stichopus chloronotus. Each circle represents a different haplotype and the size of a circle is proportional to the freque
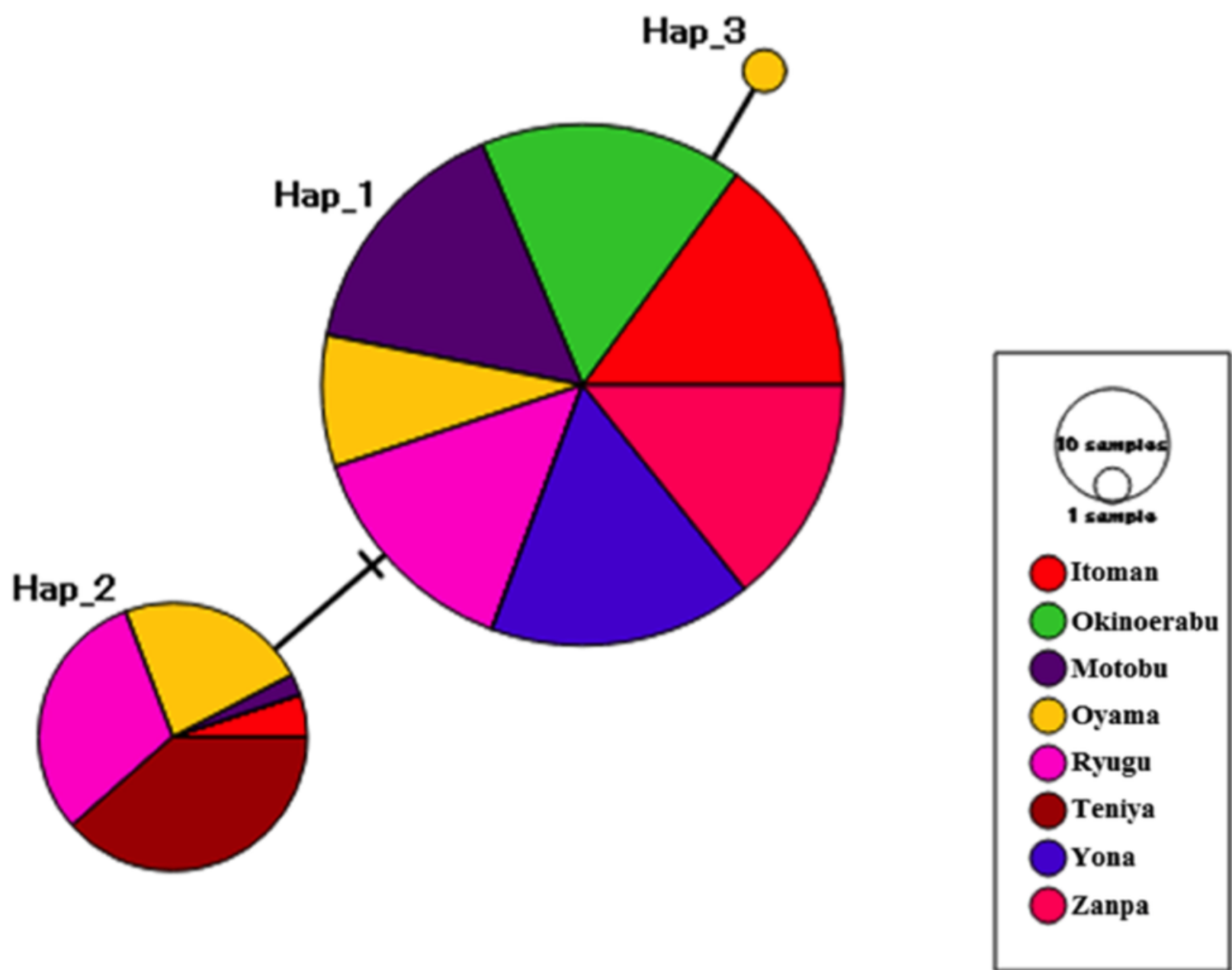


\section{Figure 3}

Average number of pairwise differences within and among populations of Stichopus chloronotus for $16 \mathrm{~S}$ ribosomal DNA.

\section{Average number of pairwise differences}

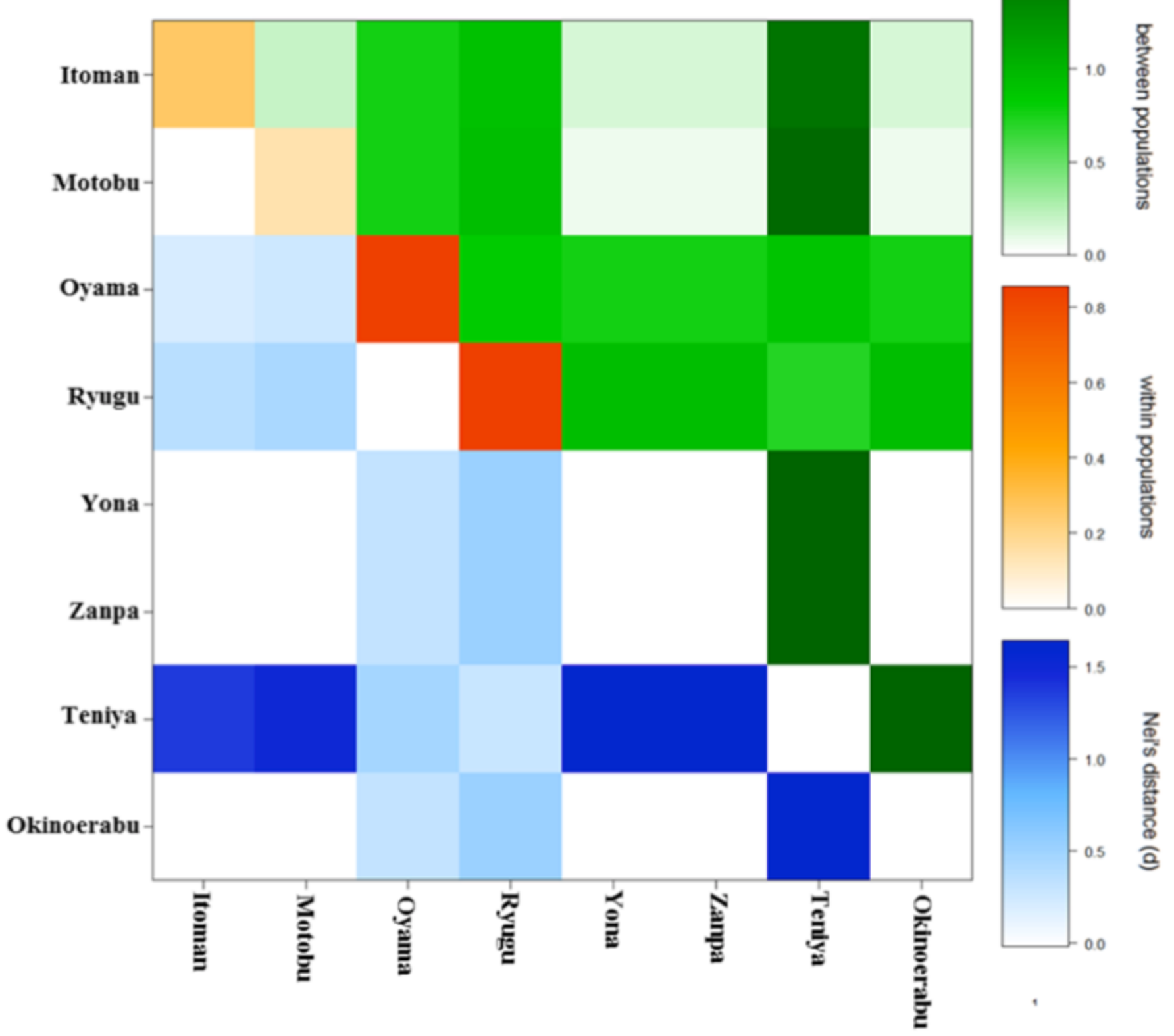


Figure 4

Principal Coordinates Analysis (PCOA) based on 16S ribosomal DNA haplotype frequencies of Stichopus chloronotus populations from Okinawa and Okinoerabu Islands.

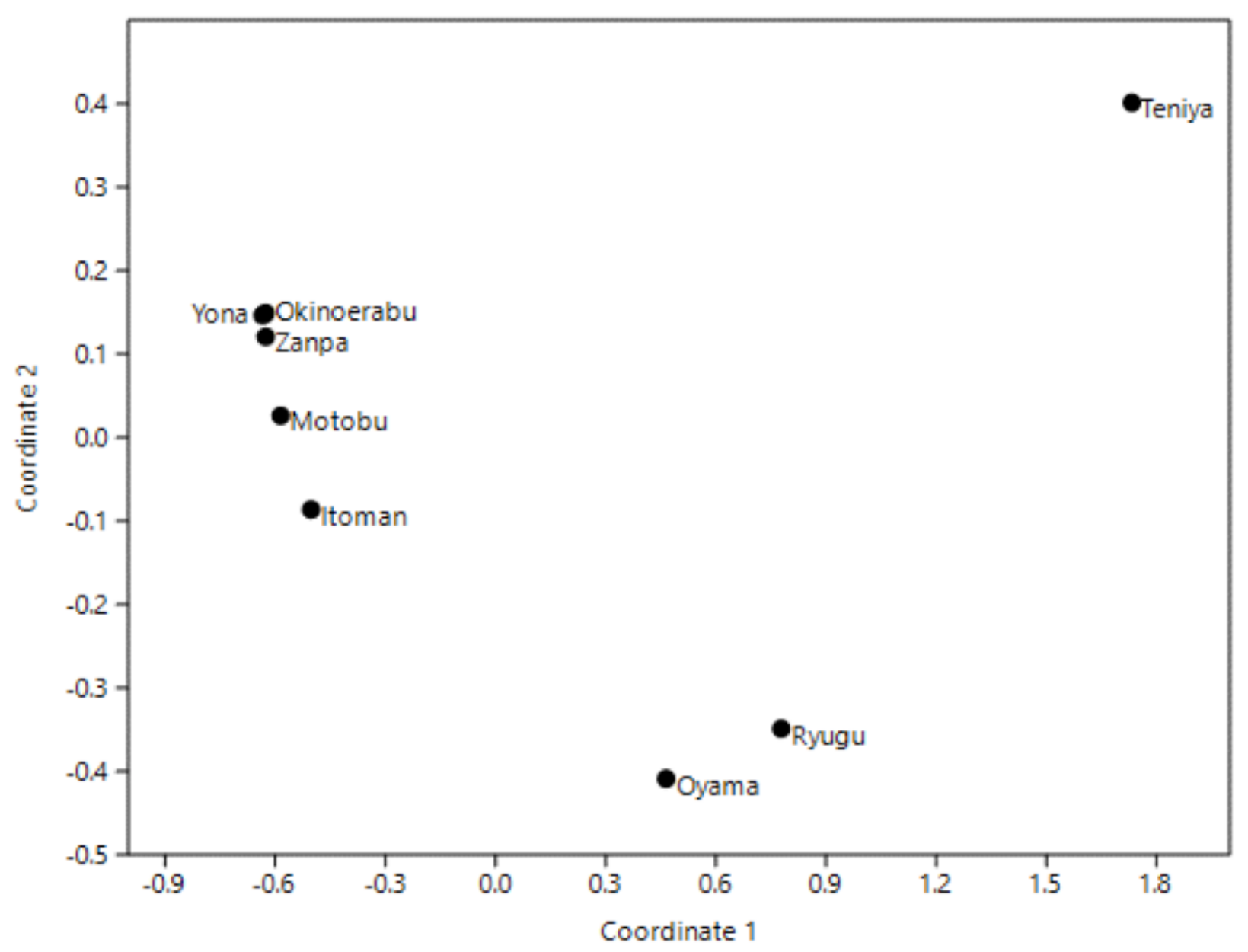

